\title{
Ophthalmic manifestations of COVID-19; a less-appreciated yet significant challenge
}

\author{
Mohsen Farvardin • Mohammadkarim Johari • Mahshid Tahamtan • \\ Mohammad-Taghi Najafi • Reza Farvardin • K. S. Jagannatha Rao • \\ Mohammad Nami 10
}

Received: 27 May 2020/ Accepted: 27 November 2020/Published online: 2 January 2021

(C) The Author(s), under exclusive licence to Springer Nature B.V. part of Springer Nature 2021

\begin{abstract}
Aim The current world has changed in all shapes since the emergence of the novel coronavirus (nCoV2) also known as COVID-19. Among the extrapulmonary manifestations of $\mathrm{nCoV}-2$, ophthalmic symptoms have less been systematically studied. The so far existing body of evidence indicates that $\mathrm{nCoV}-2$ has the potential to affect both anterior and posterior chambers of the eye. Albeit, the exact mechanisms which underlie ophthalmic manifestations of nCoV-2 are yet to be elucidated.

Methods The present brief review is an attempt to put together and highlight the significant yet limited number of studies which have spotlighted ophthalmic
\end{abstract}

\footnotetext{
M. Farvardin · M. Johari

Department of Ophthalmology, Poostchi Ophthalmology Research Center, School of Medicine, Shiraz University of Medical Sciences, Shiraz, Iran

M. Farvardin · M. Johari · M. Tahamtan

Farvardin Eye Clinic, Shiraz, Iran

M. Tahamtan · M. Nami $(\bowtie)$

Department of Neuroscience, School of Advanced

Medical Sciences and Technologies, Shiraz University of

Medical Sciences, Shiraz, Iran

e-mail: torabinami@sums.ac.ir

M. Tahamtan · M. Nami

Dana Brain Health Institute, Iranian Neuroscience

Society, Shiraz, Iran
}

issues in $\mathrm{nCoV}-2$ patients using a systematic literature search strategy.

Results All case series or reports (including both published and preprint articles) which described ocular manifestations of patients with COVID-19 and/or documented testing of SARS-COV-2 in ocular secretions via various sampling or detection methods were sought to be included.

Conclusion The ophthalmic presentations in SARSCOV-2 are often found to be salient. Raising awareness in this respect may help defining evidencebased protective measures in today's practice of ophthalmology and allied disciplines.

\author{
M.-T. Najafi \\ Harmony Healing Center, Dubai, United Arab Emirates \\ R. Farvardin \\ Students' Research Committee, Shiraz University of \\ Medical Sciences, Shiraz, Iran \\ K. S. J. Rao · M. Nami \\ Neuroscience Center, Instituto de Investigaciones \\ Científicas y Servicios de Alta Tecnología (INDICASAT \\ AIP), City of Knowledge, Panama City, Republic of \\ Panama \\ M. Nami \\ Department of Cognitive Neuroscience, Institute for \\ Cognitive Science Studies, Pardis, Tehran, Iran
}


Keywords COVID-19 $\cdot \mathrm{nCoV}-2 \cdot$ Ophthalmic manifestations $\cdot$ Conjunctivitis $\cdot$ Retinitis $\cdot$ Optic neuropathy $\cdot$ Chemosis

\section{Introduction}

Since the emergence of $\mathrm{nCoV}-2$, the need for dependable evidence-based data on the characteristic signs in afflicted patients has been rapidly rising [1]. Currently, the clinical considerations mainly stress on preventive measures at public level as well as remediating disease manifestations in hospitalized patients to decrease mortality. Given the life-threatening nature of the disease, a vast majority of recent reports have addressed the respiratory tract. Meanwhile, extra-pulmonary manifestations of nCoV-2 should not be overlooked as they often may be likewise a potentially alternative source of transmission and significant morbidity [2].

In other words, considering the fact that many individuals who contract the virus eventually recover, it is worth considering other systemic near-term and long-term consequences of the disease outside the respiratory issues caused by the $\mathrm{nCoV}-2$.

Although the nCoV-2, also known as COVID-19, is essentially affecting the respiratory tract, it may often involve extra-pulmonary sites such as the digestive tract and other organ systems [3]. The extra-pulmonary symptoms may be substantially varied ranging from headache, diarrhea, nausea, and vomiting to ophthalmic symptoms or asymptomatic infection across patients [3].

Additionally, despite the intensive work done to unveil the routes and mechanisms of nCoV-2 transmission, the spread mode is partly unclear (3). In between the lines, some investigations have strived to define possible ophthalmic manifestations (both anterior and posterior segments) in $\mathrm{nCoV}-2$ patients. To our knowledge, few studies are conducted to date into the clinical features of $\mathrm{nCoV}-2$ from ophthalmologic perspective. Given the nCoV-2 potentials in developing in vivo mutations even the ocular manifestations of the disease may substantially vary [4]. Indeed, the virus is thought to be capable of causing a wide range of ocular manifestations from anterior segment pathologies like conjunctivitis and anterior uveitis to posterior pathologies including retinitis and optic neuritis [2].

Early on, when diagnostic kits were not readily accessible even for the old types of coronaviruses, studies aimed at collecting samples from various secessions including tears. Tears' reverse-transcription polymerase chain reaction (RT-PCR) which has been often done in research to detect and genotype viral infections with ophthalmic manifestations were examined for possible presence of the virus RNA in severe acute respiratory syndrome (SARS) hospitalized patients [5].

With the paucity of research on the ophthalmic manifestations in nCOV-2, existing data on the presence of CoV-2 RNA in tear are mixed and contradictory. While according one recent study there has been no discernible viral shedding and infectivity of tears in nCoV-2 patients [1], other studies have indicated the opposite $[5,6]$. It has primarily been hypothesized that the nasolacrimal system acts as a passage to transfect the eye through the upper respiratory tract to the eye [1]. One study sampled tears using the Schirmer's test strip at several in between days 3 and 20 after $\mathrm{nCoV}-2$ symptoms started to emerge. During the time-point evaluations, 17 patients who were recruited were examined for possible ocular symptoms such as red eye, discharge, tearing, blurred vision as well as desaturated color vision. Based on this observation, only one out of 17 patients demonstrated conjunctival injection and chemosis upon hospital stay [1]. Despite positive nasopharyngeal test results, all tear samples turned to be negative. As such, the hypothesis that nasolacrimal duct acts as a conduit to cause viral shedding in tears was found to be potentially untrue [1].

Unlike this very recent study suggesting that the likelihood of nCoV-2 transmission through tears is low(1), an investigation in 2004 by Loon et al. demonstrated the presence of viral RNA in the tears of SARS-CoV patients using the RT-PCR [5]. Either way, there seem to be a need to pursue disinfection and personal protective equipment (PPE) protocols in Ophthalmology [6]. In other words, while the data of viral shedding in tears is not conclusive, the questionable presence of the virus RNA in ocular secretions and tears is still considered a hazard [2, 5, 6]. This would in turn mandate a well-defined personal protective standards by wearing mask, gown, gloves, and goggles when ophthalmologist deal with 
suspected nCoV-2 patients [6]. The practice of ophthalmology is entangled with inadvertent physical contact with patients' eyes. Over and above, the proximity between the patient and ophthalmologist upon slit lamp examination raises a particular concern (6).

The present brief review was an attempt to cement the link between the available concurrence and controversies in to-date's literature on ophthalmic manifestations in $\mathrm{nCoV}-2$ patients. A primary literature search was performed in literature databases including PubMed, EMBASE, Google Scholar, and medRxiv. Keywords were used in combination, including "COVID-19," "SARS-CoV-2," "coronavirus," "eye," "ocular," "ocular surface," “ophthalmic," and "conjunctivitis," last accessed on 28 August, 2020. A secondary literature search was conducted by identifying relevant references of initially included articles. Inclusion criteria were as follows: All case series or reports (including both published and preprint articles) that described ocular manifestations of patients with COVID-19 and/or documented testing of SARS-COV-2 in ocular secretions via various sampling or detection methods. We excluded studies that described other systemic manifestations of COVID-19 but did not mention any ocular manifestations related to the disease, nor present original data related to the eye.

\section{Anterior chamber ocular manifestations of $\mathbf{n C o V - 2}$}

According to some recent report, conjunctival congestion, conjunctivitis, epiphora, or chemosis were among common ocular symptoms in in patients with more severe systemic manifestations due to $\mathrm{nCoV}$ $2[4,7]$. These patients are generally referred to as SARS-nCoV-2. According to Ping $\mathrm{Wu}$ et al., the presence of ocular symptoms was positively correlated with signs of more severe systemic disease including higher white blood cell and neutrophil counts and higher levels of procalcitonin, C-reactive protein, and lactate dehydrogenase [7]. In addition, their observation suggested that ocular symptoms commonly emerge in patients with severe pneumonia (7). In their study, over $90 \%$ of SARS-nCoV-2 patients turned to have positive RT-PCR from nasopharyngeal swabs. On the other hand, only around $15 \%$ were found to have concurrently positive RT-PCR from conjunctival and nasopharyngeal swabs (7). In line with the above, another recent investigation by Yunyun Zhou and colleagues concluded that while the transmission of nCoV-2 from conjunctiva is controversial, it still prompts public health implications [4]. They documented that the virus RNA can be detected in the conjunctival sac of patients with nCoV-2 pneumonia (4). Nevertheless, up till today, the route through which nCoV-2 ends up in tears has remained elusive. Some theories propose conjunctiva as the frontline inoculation site of $\mathrm{nCoV}-2$ infected droplets. Others have suggested the migration of upper respiratory tract infection through the nasolacrimal duct or even hematogenous infection of the lacrimal gland $[2-4,7,8]$. That said, further empirical and observational studies need to further investigate the same.

While the patients' ocular symptoms are found to be generally mild and self-limiting, small pieces of conjunctival hemorrhage have also been reported [3].

With respect to the anterior chamber ocular manifestations of $\mathrm{nCoV}-2$ in children, Nan $\mathrm{Ma}$, et al., reported a $22 \%$ prevalence. In details, $55 \%$ presented with increased conjunctival discharge and congestion. Other ocular manifestations were eye rubbing $(38.8 \%)$, ocular pain $(8.2 \%)$, tearing $(4.1 \%)$, and eyelid swelling (8.2\%) [9].

The angiotensin-converting enzyme 2 (ACE-2) receptors are known to be abundantly distributed among many tissues and cell types such as conjunctiva. In addition, it has been shown that the nCoV-2 invades the host cells through recognizing and binding to its potential host receptor, i.e., ACE-2. Accordingly, some reports have indicated that $\mathrm{nCoV}-2$ may potentially spread via direct or indirect contact with mucous membranes in the eyes [1, 3, 7]. Additionally, some recent reports have brainstormed on possible pathophysiology inspired by ocular models from the nCoV2 , eye, and immunity perspectives $[10,11]$.

Taken together, it appears that a properly institutionalized PPE and disinfection protocols would be expected to cut off transmission routes and avert cross infection in favor safety in ophthalmology practice.

\section{Posterior segment manifestations of $\mathrm{nCoV}-2$}

There are some reports highlighting the neurological manifestations of $n \mathrm{CoV}-2[12,13]$. Since retina is considered as an outpouching of the central nervous 


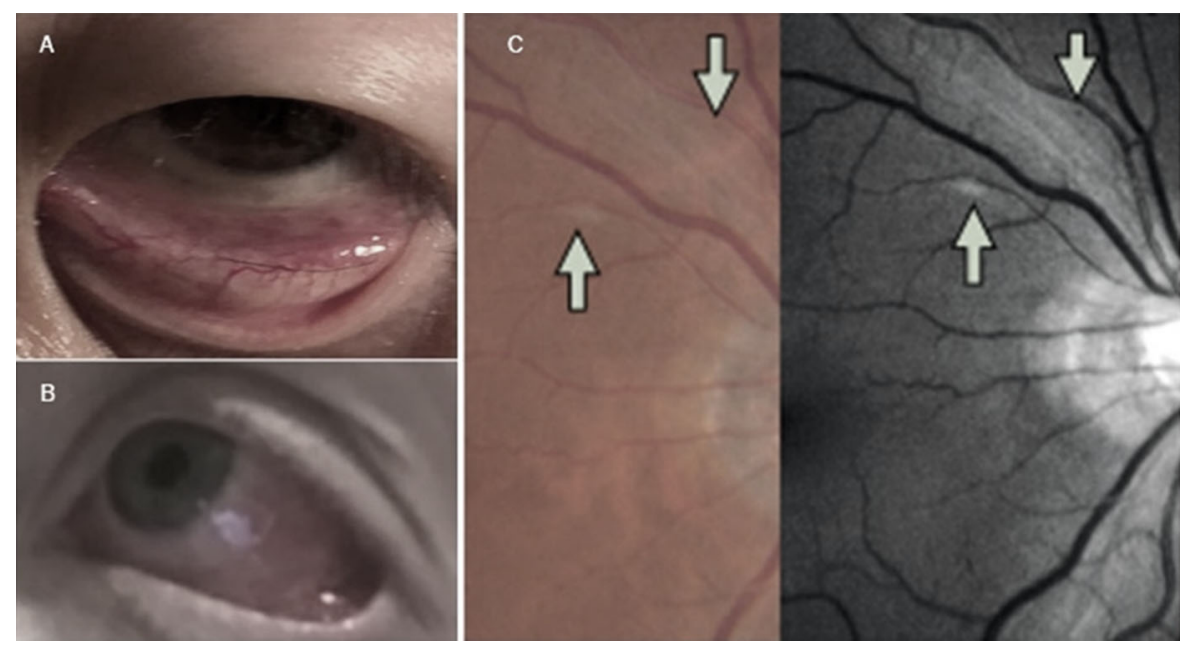

Fig. 1 Snapshots from ocular manifestations of nCoV-2. The left eye photograph of an 81 year-old nCoV-2 male patient showing a significant conjunctival congestion a, courtesy of [8]. Examination revealed unilateral eyelid edema and moderate conjunctival hyperemia. A few hours later, the patient experienced intense headache and developed fever, cough and

system (CNS), there could possibly be a link to justify involvement of not only the optic nerve (optic neurites), but also the retina (retinitis) in neuroinflammatory processes, including CNS infections [14]. The CNS is protected from viruses with its multilayer barriers and its immune response system. However, different viruses can affect the brain through a variety of mechanisms. Some proposed mechanisms by which the virus can cause infection include direct brain injury, hypoxic damage, upregulated ACE-2 receptors, and immune insufficiency [13]. The virus can potentially cause direct CNS (including retinal and optic nerve) injury through different mechanisms [15], i.e., via blood circulation where the virus is released into the blood causing an increase in the permeability of the blood-brain barrier leading to the virus-related insults $[15,16]$. Some viruses can also cause direct damage to the CNS by involving the nerve endings [17].

Paula M Marinho and colleagues used optical coherence tomography (OCT) to examine patients with SARS-nCoV-2. This has been done 11-33 days after the onset of symptoms. All patients showed hyper-reflective lesions at the level of ganglion cell and inner plexiform layers predominantly at the papillomacular bundle in both eyes. Nonetheless, the results of the OCT-angiography and the analysis of severe dyspnea. A nasopharyngeal swab proved positive for SARS-CoV-2 b., Courtesy of [21]. Color fundus photography and red-free imaging showing a cotton wool spot at the superior retinal arcade with subtle microhemorrhage (Carrows), courtesy of [18].

ganglion cells complex were found to be within normal limits. Some patients were also found to present cotton wool spots and microhemorrhages along the retinal arcade (Fig. 1). Authors inferred that their findings in ganglion cell and plexiform layers could potentially be associated with CNS manifestations [18]. Meanwhile, a recent commentary by Vavvas and his colleagues argued such findings, as they believed those OCT findings were resembling cotton wool spots (CWSs) which could be identified in a wide range of pathologies including diabetic retinopathy or hypertensive retinopathy. Also, they showed that normal inner retinal vessels in terms of the morphology, reflectivity, location, and associated posterior shadowing can mimic Marinho et al., COVID-19 OCT findings [19].

As for the retinal damage, one more thing has sadly added upon challenges in today's nCoV-2 crisis. Following the spread of rumors that alcohol consumption reduces the risk of $\mathrm{nCoV}-19$, the overuse of alcohol became an issue. This has become even more problematic when homemade alcoholic drinks which often contained methanol raised the red flag of high incidence of methanol toxic optic neuropathy (mTON) and ultra-low vision or often legal blindness seen in a large number of individuals who came to our doors. This might has been an issue in similar regions where 
Table 1 Outline of to-date studies reporting ocular manifestations of COVID-19. The summarized data indicate that putatively over $4 \%$ of the cases with confirmed COVID-19 (95outof2228) across studies were found to demonstrate ocular signs and symptoms requiring clinical attention. NCOM: Number of nCoV-2 cases with Ocular Manifestations, PCS: Prospective Case Series, RCS: Retrospective Case Series, RS: Retrospective Survey, CR: Case Report

\begin{tabular}{|c|c|c|c|c|c|c|}
\hline Ref & Authors & $\begin{array}{l}\text { Study } \\
\text { type }\end{array}$ & $\begin{array}{l}\text { No. of } \\
\text { subjects }\end{array}$ & nCoV-2 Detection Method & $\begin{array}{l}\mathrm{NCOM} \\
(\%)\end{array}$ & Ocular manifestations \\
\hline$[1]$ & Jun et al & PCS & 17 & Schirmer's test strip, RT-PCR & $0(0 \%)$ & Conjunctival injection, chemosis \\
\hline$[22]$ & Xia et al & PCS & 30 & Conjunctival swab, RT-PCR & $1(3.33 \%)$ & Conjunctivitis \\
\hline [23] & $\begin{array}{l}\text { Deng } \\
\text { et al }\end{array}$ & PCS & 114 & Conjunctival swab, RT-PCR & $0(0 \%)$ & None \\
\hline$[24]$ & $\begin{array}{l}\text { Guan } \\
\text { et al }\end{array}$ & RCS & 1099 & NA & $9(0.81 \%)$ & Conjunctival congestion \\
\hline$[25]$ & Wu et al & RCS & 38 & Conjunctival swab, RT-PCR & ${ }^{12}(31.57)$ & Conjunctival hyperemia, chemosis, epiphora \\
\hline [4] & $\begin{array}{l}\text { Zhou } \\
\text { et al }\end{array}$ & RCS & 63 & Conjunctival swab, RT-PCR & $1(1.47)$ & Conjunctivitis \\
\hline$[26]$ & Sun et al & RCS & 102 & Conjunctival swab, RT-PCR & $2(0.01 \%)$ & Conjunctivitis \\
\hline [27] & $\begin{array}{l}\text { Liang } \\
\text { et al }\end{array}$ & RCS & 37 & Conjunctival swab, RT-PCR & $3(8.1 \%)$ & $\begin{array}{l}\text { Conjunctival congestion and other inflammatory } \\
\text { appearance }\end{array}$ \\
\hline$[28]$ & $\begin{array}{l}\text { Chen } \\
\text { et al }\end{array}$ & $\mathrm{RCS}$ & 534 & NA & 25 (4.68\%) & Dry eye, blurred vision, foreign body sensation \\
\hline [29] & $\begin{array}{l}\text { Parmet } \\
\text { et al }\end{array}$ & RCS & 121 & Conjunctival swab, RT-PCR & $8(6.61 \%)$ & $\begin{array}{l}\text { Itching, redness, tearing, discharge, foreign } \\
\text { body sensation }\end{array}$ \\
\hline$[30]$ & $\begin{array}{l}\text { Lescure } \\
\text { et al }\end{array}$ & RCS & 5 & NA & $1(20 \%)$ & Conjunctivitis \\
\hline$[31]$ & $\begin{array}{l}\text { Scalinci } \\
\text { et al }\end{array}$ & $\mathrm{RCS}$ & 5 & NA & $5(100 \%)$ & $\begin{array}{l}\text { Conjunctival hyperemia, epiphora, discharge, } \\
\text { photophobia }\end{array}$ \\
\hline$[8]$ & $\begin{array}{l}\text { Hong } \\
\text { et al }\end{array}$ & RS & 56 & NA & 21 & $\begin{array}{l}\text { Itching, foreign body sensation, tearing, redness, } \\
\text { dry eyes, eye secretions, floaters }\end{array}$ \\
\hline$[32]$ & $\begin{array}{l}\text { Chen } \\
\text { et al }\end{array}$ & $\mathrm{CR}$ & 1 & Conjunctival swab, RT-PCR & $1(100 \%)$ & $\begin{array}{l}\text { Bilateral follicular conjunctivitis, foreign body } \\
\text { sensation, epiphora }\end{array}$ \\
\hline [33] & $\begin{array}{l}\text { Colavita } \\
\text { et al }\end{array}$ & $\mathrm{CR}$ & 1 & Conjunctival swab, RT-PCR & $1(100 \%)$ & Bilateral conjunctivitis \\
\hline$[34]$ & $\begin{array}{l}\text { Guillen } \\
\text { et al }\end{array}$ & $\mathrm{CR}$ & 1 & NA & $1(100 \%)$ & Conjunctivitis \\
\hline$[35]$ & $\begin{array}{l}\text { Cheema } \\
\text { et al }\end{array}$ & $\mathrm{CR}$ & 1 & $\begin{array}{l}\text { Retrospective testing of } \\
\text { conjunctival swab, RT-PCR }\end{array}$ & $1(100 \%)$ & Unilateral conjunctivitis, photophobia, epiphora \\
\hline$[36]$ & $\begin{array}{l}\text { Salducci } \\
\text { et al }\end{array}$ & $\mathrm{CR}$ & 1 & NA & $1(100 \%)$ & $\begin{array}{l}\text { Bilateral conjunctivitis, photophobia, aqueous } \\
\text { secretion, chemosis, pseudo-membranes }\end{array}$ \\
\hline [37] & $\begin{array}{l}\text { Daruich } \\
\text { et al }\end{array}$ & $\mathrm{CR}$ & 1 & NA & $1(100 \%)$ & Foreign body sensation, red eye \\
\hline$[25]$ & Wu et al & $\mathrm{CR}$ & 1 & N/A & 1 & Conjunctivitis, eyelid dermatitis \\
\hline \#20 & N/A & N/A & 2228 & NA & $\begin{array}{l}95 \\
\quad(4.12 \%)\end{array}$ & N/A \\
\hline
\end{tabular}

alcohol is banned or not readily accessible (20). As such, public awareness campaigns and academic efforts need to get synergized to reduce such an ongoing catastrophe.

Studies including prospective and retrospective case series, retrospective surveys or case reports (both published and preprint document) which described ocular manifestations of patients with COVID-19 and/ or documented testing of SARS-COV-2 in ocular secretions via various sampling or detection methods were sought to be included. Table 1 summarizes data which putatively suggest an overall prevalence of 
$4.12 \%$ for ocular signs and symptoms requiring clinical attention in nCoV-2 patients (Table 1).

\section{Concluding remarks}

Though the existing body of evidence reassures that the transmission of nCoV-2 via ocular surface is low, nosocomial routes of the virus spread to the eyes after occupational exposure is still a potential concern. Due to the sampling time lag and the fact that diagnostic methods are often inefficient; like other health care providers, ophthalmologists need to strictly follow the PPE protocols [6].

Taking the so far evidence in to account, conjunctivitis seems to be an initial ocular symptom of nCoV2. It has been shown that $n \mathrm{CoV}-2$ patients with conjunctivitis tend to spread the virus in the tears. Regardless of symptomatic or asymptomatic ophthalmic profile of patients with $\mathrm{nCoV}-2$, the risk of patient-to-ophthalmologist disease transmission should always receive attention.

\section{Compliance with ethical standards}

Conflict of Interest The authors declare that they have no competing interest.

\section{References}

1. Jun ISY, Anderson DE, Kang AEZ, Wang L-F, Rao P, Young BE et al (2020) Assessing viral shedding and infectivity of tears in coronavirus disease 2019 (COVID-19) patients. Ophthalmology 127(7):977-979

2. Seah I, Agrawal R (2020) Can the coronavirus disease 2019 (COVID-19) affect the eyes? A review of coronaviruses and ocular implications in humans and animals. Ocular immunol inflammation 28(3):391-395

3. Sun X, Zhang X, Chen X, Chen L, Deng C, Zou X, et al. The infection evidence of SARS-COV-2 in ocular surface: a single-center cross-sectional study. MedRxiv. 2020.

4. Zhou Y, Zeng Y, Tong Y, Chen C. Ophthalmologic evidence against the interpersonal transmission of 2019 novel coronavirus through conjunctiva. MedRxiv. 2020.

5. Loon S, Teoh S, Oon L, Se-Thoe S, Ling A, Leo Y et al (2004) The severe acute respiratory syndrome coronavirus in tears. Br J Ophthalmol 88(7):861-863

6. Seah I, Su X, Lingam G. Revisiting the dangers of the coronavirus in the ophthalmology practice. Nature Publishing Group; 2020.

7. Wu P, Duan F, Luo C, Liu Q, Qu X, Liang L et al (2020) Characteristics of ocular findings of patients with coronavirus disease 2019 (COVID-19) in Hubei Province. China, JAMA ophthalmology

8. Hong N, Yu W, Xia J, Shen Y, Yap M, Han W (2020) Evaluation of ocular symptoms and tropism of SARS-CoV2 in patients confirmed with COVID-19. Can J Ophthalmol. https://doi.org/10.1016/j.jcjo.2020.11.006

9. Ma N, Li P, Wang X, Yu Y, Tan X, Chen P et al (2020) Ocular Manifestations and Clinical Characteristics of Children With Laboratory-Confirmed COVID-19 in Wuhan. China. JAMA ophthalmol 138(10):1079-1086

10. Neri P, Lamperti M, Pichi F, SARS-COV-2 and eye immunity: the lesson was learned but we are not done yet, (2020) Brainstorming on possible pathophysiology inspired by ocular models. Int Ophthalmology. 40(8):1879-1883

11. Neri P, Pichi F (2020) COVID-19 and the eye immunity: lesson learned from the past and possible new therapeutic insights. Int Ophthalmol 40(5):1057-1060

12. Mao L, Jin H, Wang M, Hu Y, Chen S, He Q et al (2020) Neurologic manifestations of hospitalized patients with coronavirus disease 2019 in Wuhan. China, JAMA neurology

13. Wu Y, Xu X, Chen Z, Duan J, Hashimoto K, Yang L et al (2020) Nervous system involvement after infection with COVID-19 and other coronaviruses. Brain, Behav Immunity. 87:18-22

14. Afarid M, Torabi-Nami M, Zare B (2016) Neuroprotective and restorative effects of the brain-derived neurotrophic factor in retinal diseases. J Neurol Sci 363:43-50

15. Koyuncu OO, Hogue IB, Enquist LW (2013) Virus infections in the nervous system. Cell Host Microbe 13(4):379-393

16. Unni SK, Růžek D, Chhatbar C, Mishra R, Johri MK, Singh SK (2011) Japanese encephalitis virus: from genome to infectome. Microbes Infect 13(4):312-321

17. Swanson PA II, McGavern DB (2015) Viral diseases of the central nervous system. Current opinion in virol 11:44-54

18. Marinho PM, Marcos AA, Romano AC, Nascimento H, Belfort R (2020) Retinal findings in patients with COVID19. The Lancet. https://doi.org/10.1038/s41433-020-012832

19. Vavvas DG, Sarraf D, Sadda SR, Eliott D, Ehlers JP, Waheed NK, et al. Concerns about the interpretation of OCT and fundus findings in COVID-19 patients in recent Lancet publication. Nature Publishing Group; 2020.

20. Lankarani KB, Afshari R (2014) Alcohol consumption in Iran. Lancet 384(9958):1927-1928

21. Daruich A, Martin D, Bremond-Gignac D. Ocular manifestation as first sign of Coronavirus Disease 2019 (COVID19): interest of telemedicine during the pandemic context. Journal Français d'Ophtalmologie. 2020.

22. Xia J, Tong J, Liu M, Shen Y, Guo D (2020) Evaluation of coronavirus in tears and conjunctival secretions of patients with SARS-CoV-2 infection. J Med Virol 92(6):589-594

23. Deng C, Yang Y, Chen H, Chen W, Chen Z, Ma K, et al. Ocular Dectection of SARS-CoV-2 in 114 cases of COVID19 pneumonia in Wuhan, China: An observational study. China: an observational study (2/19/2020). 2020.

24. Guan W-j, Ni Z-y, Hu Y, Liang W-h, Ou C-q, He J-x et al (2020) Clinical characteristics of coronavirus disease 2019 in China. New England J Med 382(18):1708-1720 
25. Wu P, Liang L, Chen C, Nie S. A child confirmed COVID19 with only symptoms of conjunctivitis and eyelid dermatitis. Graefe's Archive for Clinical and Experimental Ophthalmology. 2020:1.

26. Sun Y, Liu L, Pan X, Jing M (2006) Mechanism of the action between the SARS-CoV S240 protein and the ACE2 receptor in eyes. Int J Ophthalmol 6(4):783-786

27. Liang $\mathrm{L}, \mathrm{Wu} \mathrm{P}$. There may be virus in conjunctival secretion of patients with COVID-19 (2020). Acta ophthalmologica, 93(3): 223

28. Chen L, Deng C, Chen X, Zhang X, Chen B, Yu H, et al. Ocular manifestations and clinical characteristics of 534 cases of COVID-19 in China: A cross-sectional study. MedRxiv. 2020.

29. Parmet WE, Sinha MS (2020) Covid-19-the law and limits of quarantine. N Engl J Med 382(15):e28

30. Lescure F, Bouadma L, Nguye n D. case series. Lancet Infect Dis. 2020.

31. Scalinci SZ, Battagliola ET (2020). Conjunctivitis can be the only presenting sign and symptom of COVID-19. ID Cases.20:00774.

32. Chen L, Liu M, Zhang Z, Qiao K, Huang T, Chen M et al (2020) Ocular manifestations of a hospitalised patient with confirmed 2019 novel coronavirus disease. Br J Ophthalmol 104(6):748-751
33. Viral R. Observation: Brief research report.

34. Guillen E, Pineiro GJ, Revuelta I, Rodriguez D, Bodro M, Moreno A, et al. (2020). Case report of COVID-19 in a kidney transplant recipient: does immunosuppression alter the clinical presentation? American Journal of Transplantation.

35. Cheema M, Aghazadeh H, Nazarali S, Ting A, Hodges J, McFarlane A, et al. Keratoconjunctivitis as the initial medical presentation of the novel coronavirus disease 2019 (COVID-19): A case report. Canadian Journal of Ophthalmology. 2020.

36. Salducci M, La Torre G (2020) COVID-19 emergency in the cruise's ship: a case report of conjunctivitis. Clin Ter 171(3):e189-e191

37. Daruich A, Martin D, Bremond-Gignac D (2020) Unilateral conjunctivitis as first presentation of Coronavirus Disease 2019 (COVID-19): A telemedicine diagnosis. J Français d'Ophtalmologie. 43(5):1-2

Publisher's Note Springer Nature remains neutral with regard to jurisdictional claims in published maps and institutional affiliations. 